\title{
Edukacja na rzecz etyki środowiskowej na terenach leśnych - idea Leave No Trace
}

\author{
Przemysław Płoskonka \\ Wydział Turystyki i Rekreacji, Akademia Wychowania Fizycznego Józefa Piłsudskiego w Warszawie \\ ul. Marymoncka 34, 00-968 Warszawa \\ przemyslaw.ploskonka@awf.edu.pl• ORCID 0000-0003-0178-1606
}

\begin{abstract}
Streszczenie
Artykuł charakteryzuje jedną z popularnych na świecie koncepcji edukacji na rzecz etyki środowiskowej (etyka outdorowa) - Leave No Trace. Początkowo program był skierowany głównie do środowisk związanych z górami przewodników, wspinaczy, turystów górskich - jako odpowiedź na dewastację i zaśmiecanie gór. Obecnie został on rozszerzony na inne obszary przyrodnicze, w tym środowisko leśne. Model etyki środowiskowej (outdoorowej) Leave No Trace promuje odpowiedzialne postawy (zwiększanie świadomości społecznej). Rdzeń koncepcji oparty jest na siedmiu uniwersalnych zasadach, które w połączeniu z przekazywaną wiedzą oraz nabywanymi umiejętnościami mają za zadanie minimalizować wpływ człowieka na środowisko przyrodnicze, w którym przebywa.
\end{abstract}

\section{Słowa kluczowe}

edukacja przyrodniczo-leśna, tereny leśne, leave no trace

\section{Wstęp}

W ostatnich latach wzrasta zapotrzebowanie na edukację społeczeństwa opartą na rzetelnej wiedzy przyrodniczej, która pozwoli zrozumieć sens ochrony przyrody, zaczynając od problemów lokalnych, po globalne. Wzrost zainteresowania terenami leśnymi stanowi wyzwanie dla współczesnej edukacji przyrodniczo-leśnej. Istotne stają się działania służące podnoszeniu świadomości społeczeństwa w zakresie racjonalnego i odpowiedzialnego korzystania z lasu, minimalizowania wpływu człowieka na środowisko naturalne oraz przeciwdziałania konsumpcyjnemu nastawieniu do przyrody.

Właściwa i skuteczna ochrona środowiska uzależniona jest od poziomu wiedzy społeczeństwa i preferowanych stylów życia. Zarówno bowiem wiedza, jak i styl życia podlegają ciągłym zmianom, głównie dzięki edukacji. Człowiek jest odbiciem własnych doświadczeń, dlatego żyjąc z dala od przyrody, jesteśmy kształtowani przez wytwory współczesności: plastik, metal, szkło, codzienny zaś sposób życia, postawy i nawyki są ściśle związane z cywilizacją (post)industrialną. Żeby edukacja przyrodniczo-leśna miała sens, tego typu działania muszą mieć charakter permanentny i być w miarę spójne z życiem, jakie się prowadzi codziennie (Kulik, Kukowska 2010: 6). Tym bardziej, że coraz częściej edukacja opiera się przede wszystkim na przekazywaniu informacji, a nie zdobywaniu wiedzy. 
A im mniej prawdziwej wiedzy, tym jeszcze mniej mądrości. Ta bowiem wyrasta z głębi zrozumienia tego, co znane i świadomości wzajemnych powiązań. Wielkim dylematem edukacji na rzecz przyrody jest to, że z jednej strony chcemy do jej wartości i piękna przekonać jak najszerszą rzeszę obywateli, a z drugiej strony ograniczamy dostęp, żeby uniknąć zagrożeń (Węsławski 2015: 253-254). A przecież wszystkie zachowania - również te związane z przyrodą - uwarunkowane są kulturowo, dlatego przyczyn współczesnych zagrożeń należy upatrywać nie tyle w złej woli, ile w zwyczajnej nieświadomości skutków własnego zachowania, najczęściej wynikającego z braku wiedzy (Kowalczyk 2008: 13-14).

Nowoczesna edukacja przyrodniczo-leśna powinna zatem skupiać się na podnoszeniu świadomości współzależności przyczyn i konsekwencji zachowań oraz kształtowaniu postaw i norm etycznych sprzyjających odpowiedzialnemu korzystaniu z zasobów przyrodniczych. Jedną z interesujących koncepcji, wpisujących się w powyższe założenia, jest idea etyki środowiskowej (outdoorowej) - Leave No Trace, czyli nie pozostaw żadnego śladu. Program jest realizowany od ponad 20 lat, jego zaś celem jest promowanie odpowiedzialnych zachowań sprzyjających minimalizowaniu wpływu na środowisko naturalne podczas działalności plenerowej (turystyczno-rekreacyjnej).

\section{Leave No Trace - geneza i uwarunkowania}

Zachodzące w drugiej połowie XX w. przemiany społeczne i gospodarcze w Stanach Zjednoczonych Ameryki spowodowały wzrost zainteresowania rekreacją na świeżym powietrzu. Ucieczka na łono przyrody - poza granice rozrastających się aglomeracji - stała się antidotum na bolączki miejskiego życia, rozwój zaś infrastruktury drogowej umożliwiał dotarcie do najdzikszych zakątków kraju. Równocześnie na forum publicznym ścierały się dwie koncepcje udostępnienia dzikich terenów - liberalna, wywodzącą się z tradycji puszczańskich i scoutowych, postulująca swobodny dostęp do tych terenów, oraz konserwatywna, domagająca się biernej ochrony przyrody i rygorystycznych ograniczeń (Turner 2002: 462-463). W 1964 r., po licznych poprawkach i zmianach, zatwierdzono Ustawę o dzikiej przyrodzie (web-o1) stanowiącą do dzisiaj najważniejszy akt regulujący zasady ochrony i korzystania z przyrodniczo cennych terenów Stanów Zjednoczonych. Ustawa wprowadziła formalne pojęcie dziczy (wilderness) jako obszaru, który - w przeciwieństwie do terenów, na których człowiek oraz jego działalność mają dominujące znaczenie - jest autonomiczny i umożliwia nieskrępowany rozwój przyrodzie, sam zaś człowiek jest tam jedynie gościem (web-o1). Utworzony narodowy system ochrony dzikiej przyrody (National Wilderness Preservation System) objął swym zasięgiem wybrane tereny, które zachowały naturalny czy wręcz pierwotny charakter (znikomy wpływ działalności ludzkiej) oraz posiadały wartości edukacyjne, naukowe lub historyczne. Na obszarach podlegających regulacjom, mimo obostrzeń dotyczacych m.in. infrastruktury i transportu mechanicznego, dozwolona była nieograniczona turystyka i rekreacja.

Istotne zmiany nastąpiły na przełomie lat 70. i 80. XX w. związane z dynamicznie rozwijającym się ruchem campingowym. Biwakowanie w plenerze, połączone z pieszymi wędrówkami i backpackingiem ${ }^{1}$, stało się popularną formą spędzania czasu wolnego. Jak zauważają Simon i Alagona (2009: 1920), nastąpiła również zmiana w postawach odwiedzających, dla których wzorce poszanowania natury i etyka oparta na starej szkole woodcraft ${ }^{2}$ (puszczaństwo) stały się

1 Backpacking (z ang. podróż z plecakiem) forma aktywności polegająca na podróżowaniu pieszo z plecakiem, najczęściej w bliskim kontakcie z naturą. Może być powiązana z biwakowaniem w plenerze, cały niezbędny sprzęt (odzież, żywność, sprzęt biwakowy i kuchenny, inny) jest przenoszony „na plecach”, czas trwania wynosi co najmniej jeden dzień. (Źródło: web-02).

2 Woodcraft (Puszczaństwo) - idea postulująca wychowanie człowieka poprzez rekreację na łonie 
obce. Ekspansja przemysłu outdorowego, wsparta rozwojem technologii - odzież Gore-tex, podeszwy Vibram, nylonowe namioty, przenośne kuchenki i ręczne urządzenia do oczyszczania wody, rozbudziła nowe potrzeby konsumpcyjne i przyczyniła się do uformowania pokolenia turystów high-tech, dla których sprzęt stał się niezbędnym łącznikiem umożliwiającym zbliżenie do natury. Atrakcyjność turystyczna obszarów przyrodniczo cennych spowodowała lawinowy wzrost liczby odwiedzających i wpłynęła na zwiększenie presji na te tereny. Konsumpcyjne nastawienie do przyrody i brak świadomości negatywnych oddziaływań przyczyniły się do degradacji popularnych miejsc campingowych i szlaków turystycznych (Turner 2002: 477). Zjawisko to zapoczątkowało proces poszukiwania kompromisowych rozwiązań, które z jednej strony nie ograniczą dostępu do terenów przyrodniczo cennych, a z drugiej pozwolą zachować ówczesny stan przyrody dla potomnych.

Początkowe działania opierały się na podejściu regulacyjnym i przejawiały się m.in. wprowadzaniem limitów i ograniczeń dla odwiedzających parki narodowe i pozostałe obszary podlegające ochronie. Liczne publikacje z tego okresu promowały jednak edukacyjne, a nie regulacyjne podejście do zarządzania rekreacją na obszarach przyrodniczo cennych i zwracały uwagę, iż edukacja jest działaniem prewencyjnym, uczącym ludzi, jak zachować się na łonie przyrody bez jej niszczenia. Wszystkie inne metody jedynie naprawiają wyrządzone szkody. Efektywniejsza edukacja zmniejszy potrzebę regulacji prawnych i przyczyni się do świadomego korzystania z przyrody (Marion, Reid 2001: 82). Jak zauważył pod koniec lat 7o. Bradley (1979: 223), podejście czysto regulacyjne było niewłaściwe, gdyż przepisy jedynie antagonizowały społeczeństwo, a nie zdobywały jego poparcia, większość

przyrody. Filozoficzna i etyczna koncepcja akcentująca łączność człowieka ze światem przyrody. (Źródło: web-04). zaś negatywnych odziaływań nie była zamierzona, a wynikała z niewiedzy. Ponadto możliwości egzekwowania prawa na rozległych i odludnych terenach lasów i parków narodowych były mocno ograniczone.

Przesłankami zmian były słowa dyrektora Służby Leśnej (USFS) Maxa Petersona, iż sposób wykorzystania dzikich terenów wynika w $80-90 \%$ z edukacji, a w $10 \% \mathrm{z}$ regulacji prawnych (za: Marion, Reid 2001: 81). Poszczególne jednostki agencji federalnych odpowiedzialnych za lasy (USFS), parki narodowe (NPS) i gospodarowanie gruntami (BLM) - podjęły spontaniczne działania edukacyjne przejawiające się w wydawaniu broszur informacyjnych na temat etyki outdoorowej, sposobów zachowania w plenerze oraz ograniczenia wpływu campingu na przyrodę (Wilderness Ethics, Minimum Impact Camping, No-Trace Camping). Wiadomości były zamieszczane na tablicach ogłoszeń, leśniczy zaś rozmawiali z ludźmi, których spotkali na patrolu, o zalecanych formach zachowania na szlaku i w obozie (Cole 2018: 2-3). Do działań aktywnie włączyły się National Outdoor Leadership School (NOLS) - czołowa szkoła z ponad 25-letnim doświadczeniem w kształceniu liderów edukacji plenerowej, etyki środowiskowej i umiejętności bytowania w dziczy oraz Boy Scouts of America, natomiast wytwórcy sprzętu outdorowego (REI, Nort Face) zaczęli umieszczać informacje edukacyjne na swoich produktach. Większość realizowanych projektów miała charakter lokalny i nie była zinstytucjonalizowana. Z czasem programy realizowane na terenie dziesiątków parków, obszarów dzikiej przyrody i lasów przybrały nieformalny charakter etyki dzikiej przyrody i zrównoważonych praktyk podróżowania oraz biwakowania. Za wspólny mianownik uznano działanie służące niepozostawianiu po sobie śladu podczas bytowania w plenerze, nadając realizowanym programom nazwę "No Trace" (Swain 1996: 24). W połowie lat 80. wpływowy magazyn podróżniczy „Outside” odnotował rosnącą liczbę świadomych obozowiczów, którzy starali się ograniczyć swój 
wpływ na otoczenie, czy wręcz nie pozostawić żadnego śladu po swojej bytności. Z podziwem opisywał też przypadki fanatyków, którzy na powrót układali trawę w miejscu biwaku, czy zrezygnowali z papieru toaletowego, aby nie kopać dołków w ziemi (za: Turner 2002: 462).

Przełomem okazał się rok 1985. Latem, Jim Ratz, dyrektor generalny National Outdoor Leadership School (NOLS), zaprosił grupę kierowników, badaczy i pracowników naukowych Służby Leśnej (FSR) i Biura Gospodarki Gruntami (BLM) na trzydniową wyprawę po odludziach Popo Agie w Wyoming (Popo Agie Wilderness). Podczas wyprawy zaprezentował opracowany przez NOLS zbiór zasad w zakresie ochrony przyrody (NOLS Conservation Practices) oraz zaproponował współpracę w celu propagowania wiedzy na temat zachowań ograniczających wpływ na środowisko naturalne. Propozycja zostało bardzo dobrze przyjęta, w wyniku podjętych prac uporządkowano i usystematyzowano liczne zalecania i zasady związane z dziką przyrodą (przemieszczanie się w terenie, biwakowanie, użytkowanie ognia, urządzeń sanitarnych, utylizacja śmieci, inne), ujmując je w zbiór 75 zalecanych praktyk wraz z opisem problemu, zalecanymi działaniami oraz ich uzasadnieniem. Pod koniec lat 8o. nastąpiła rewizja zasad stosowanych przez NOLS, wydzielenie reguł w zależności od specyfiki terenu (pustynia, wybrzeża, tundra itp.) i wydanie we współpracy ze Służbą Leśną (FSR) książki Soft pants, czyli jak korzystać z przyrody bez jej niszczenia. Opracowano również zbiór sześciu zasad, uzupełniając go o dodatkowe siódme zalecenie (za: Cole 2018: 6):

- w popularnych miejscach turystycznych działaj w sposób skoncentrowany,

- w dziczy staraj się oddziaływać w sposób rozproszony,

- omijaj miejsca, w których wpływ na przyrodę dopiero się rozpoczął,

- $\quad$ zabierz wszystko, co przyniosłeś,

- $\quad$ odpowiednio pozbądź się rzeczy, których nie możesz zabrać,
- pozostaw rzeczy w takim stanie, w jakim je zastałeś lub lepszym,

- ogranicz hałas i nie narzucaj się innym.

Rozpoczęta współpraca zaowocowała decyzją o stworzeniu ogólnokrajowego programu etyki outdorowej. W 1991 r. partnerstwo Służby Leśnej (USFS) z NOLS został sformalizowane, zaś program przyjął oficjalną nazwę Leave No Trace (LNT). NOLS wykorzystując wieloletnie doświadczenie przygotował merytoryczne treści programu oraz opracował system szkoleń i kursów. Pierwszy pilotażowy kurs LNT Masters odbył się jeszcze tego samego roku i został przeznaczony dla pracowników Służby Leśnej (USFS) oraz Biura Gospodarki Gruntami (BLM). W następnych latach do projektu dołączyły pozostałe agencje federalne, odpowiedzialne za ochronę obszarów przyrodniczo cennych. Podjęta współpraca doprowadziła do podpisania memorandum pomiędzy zaangażowanymi stronami oraz zobowiązała wszystkich partnerów do wdrożenia programu na poziomie federalnym, wspólnej dystrybucji materiałów szkoleniowych oraz wzajemnego wsparcia w dalszym rozwoju modelu edukacyjnego LNT (Cole 2018: 6-7). Dzięki tym działaniom program LNT zyskał ogólnokrajowy zasięg, a wsparcie - m.in. Boy Scouts of America, American Camp Association, ośrodków akademickich czy firm outdorowych - pozwoliło dotrzeć do szerokiego grona odbiorców i stało się oficjalną doktryną świadomych i odpowiedzialnych turystów.

Aktualnie projekt LNT (ryc. 1) jest prowadzony i koordynowany przez organizację non-profit Leave No Trace Center for Outdoor Ethics (LNTOE), w stałym partnerstwie z pozostałymi partycypantami. Misją LNTOE jest nauczenie ludzi odpowiedzialnego korzystania z przyrody poprzez edukację, badania, wolontariat i partnerstwo. Zasięg programu już dawno wykroczył poza granice Stanów Zjednoczonych i zyskał na całym świecie uznanie oraz liczne grono współpracowników. Na terenie Polski oficjalnym partnerem (Active Partner) LNTOE jest Stowarzyszenie Polska Szkoła Surwiwalu. 


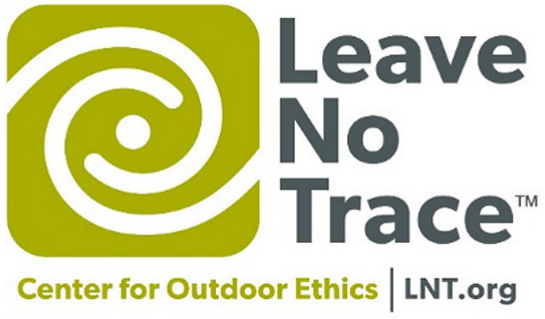

Ryc. 1. Oficjalne logo Leave No Trace Center for Outdoor Ethics (źródło: https://lnt.org)

\section{Leave No Trace - podstawy programowe}

Edukacyjny model LNTOE kładzie nacisk na rozwój oraz upowszechnianie wiedzy, umiejętności i postaw w ramach etyki outdorowej. Zasób wiadomości wykorzystywany w modelu edukacji LNTOE pochodzi z różnych źródeł - zaangażowanych agencji federalnych, badań naukowych, przemysłu outdorowego i edukatorów terenowych. Mocną stroną projektu jest również zaplecze naukowe, gdyż wypracowane zasady opierają się nie tylko na szacunku dla przyrody i innych odwiedzających, lecz także na danych empirycznych pozyskanych z badań naukowych, statystyk i innych udokumentowanych źródeł. Są one udostępnione na stronach projektu LNTOE, prezentowane podczas bezpośrednich spotkań i szkoleń oraz służą do dalszego rozwoju programu. Dostępne opracowania koncentrują się, z jednej strony, na problematyce oddziaływań (impact) człowieka na tereny przyrodniczo cenne w ramach działalności rekreacyjnej. Jak podaje Lawhon i inni (2013: 27), za podstawy teoretyczne służą prace z zakresu ekologii rekreacji (Recreation ecology), dziedziny nauki zajmującej się badaniem wpływu oraz wzajemnych powiązań i interakcji między człowiekiem a środowiskiem przyrodniczym. Z drugiej strony skupiają się na postawach społecznych związanych z procesami zarządzania, ochrony i udostępniania zasobów naturalnych. W tym przypadku pomocne stają się badania z zakresu zarządzania zasobami naturalnymi (Human dimensions of natural resources) stanowiące multidyscyplinarne podejście do zrównoważonego gospodarowania ekosystemami z uwzględnieniem korzyści wszystkich zainteresowanych. Ich celem jest również zrozumienie postaw i zachowań ludzi w kontekście wartości przyrody.

Podjęte w ramach projektu działania wsparte licznymi wynikami badań umożliwiły wyróżnienie sześciu głównych obszarów wpływu człowieka na środowisko (Web-03):

- oddziaływanie na dziką przyrodę: zmiana zachowań zwierząt, problemy ze zdrowiem, zaburzona reprodukcja zwierząt. Knight i Cole (1991: 238-246) wskazują, iż pozostawianie jedzenia w miejscach rekreacyjnych prowadzi do zmiany zachowań zwierząt i intensyfikacji spotkań z ludźmi. Ponadto autorzy zauważają, iż wpływ człowieka na zwierzęta ma inny charakter niż na rośliny. Ze względu na mobilność zwierząt zmiany mogą dotykać całej populacji;

- wpływ na wegetację: utrata roślinności, wprowadzenie gatunków inwazyjnych oraz uszkodzenia drzew i roślin. Cole i Monza (2003: 693-705) dowodzą, że nawet krótkotrwałe biwakowanie wpływa niekorzystnie na roślinność. Zbadano, iż wystarczy czterodniowy biwak na terenach leśnych, aby na około 8 lat zaburzyć wegetację roślin z najniższej warstwy lasu (runa leśnego), przy tym największy wpływ na runo leśne następuje w pierwszym roku użytkowania. W przypadku biwaku jednodniowego utrata szaty roślinnej na terenach leśnych jest blisko o połowę większa niż na łąkach;

- wpływ na stosunki (zasoby) wodne: zamulenie, sedymentacja, odpady środków myjących, fekaliów. Cilimburg, Monz i Kehoe (2000: 587-598) wskazują, że największym problemem jest nieodpowiednie usuwanie ludzkich odchodów i związane z tym zagrożenie patogenami (Giardia lamblia, 
Hepatowirus A, inne) przedostającymi się do gleby i wód powierzchniowych. Gerba (1987: 142-154) zbadał, iż czynniki chorobotwórcze pochodzące z ludzkich odchodów mogą przetrwać w glebie i wodzie kilka miesięcy. Należy jednak zaznaczyć, że dołki na odchody są najmniej inwazyjną formą pozbywania się fekaliów, przy czym Bridle i Kirkpatrick (2005:21-30) zauważają, iż bielony papier toaletowy i tampony są wysoce odporne na proces humifikacji związków próchnicznych;

- oddziaływanie na glebę: utrata warstwy organicznej, zagęszczenie gleby lub erozja gleby. Reid, Scott i Marion (2005: 48-58) dowodzą, iż intensywne palenie ogniska zmniejsza zawartość materii organicznej w glebie do głębokości co najmniej $10 \mathrm{~cm}$. Obszary narażone na częste i liczne paleniska (pola biwakowe) na skutek zmniejszenia zawartości materii organicznej i zmiany składu chemicznego gleby posiadają mniejszą zdolność do zatrzymywania wody, a tym samym są podatne na erozję i zagęszczenie;

- wpływ na dziedzictwo kulturalne: uszkadzanie i niszczenie dziedzictwa kulturalnego. Ward i Roggenbuck (2003: 67-82) zbadali, iż blisko 75\% respondentów na terenie parków narodowych nie przestrzega przepisów i powoduje znaczne szkody w zasobach i obiektach;

- $\quad$ skutki społeczne: przekroczona chłonność turystyczna (tłum), konflikty między różnymi grupami użytkowników, ograniczone doświadczenie w kontakcie z przyrodą. Manning i Valliere (2001: 410-426) podkreślają, że zwiększone wykorzystanie terenów rekreacyjnych prowadzi do licznych problemów społecznych (kradzieże, problemy z parkowaniem, hałas) oraz konfliktów interpersonalnych. Skutkuje to istotnym obniżeniem jakości doznań turystycznych (spadek poczucia wolności, prywatności, kontaktu z przyrodą) i wpływa na zmianę wzorców zachowań aktywności rekreacyjnej.

W toku analiz badacze zaproponowali hipotetyczny związek pomiędzy rekreacyjnym użytkowaniem obszarów przyrodniczych a wpływem na te tereny (ryc. 2). Zależność ma charakter geometryczny, zwiększone wykorzystanie w równym stopniu wpływa na zwiększone oddziaływanie. Należy jednak zaznaczyć, że ten wpływ może mieć różne natężenie w zależności od obszaru.

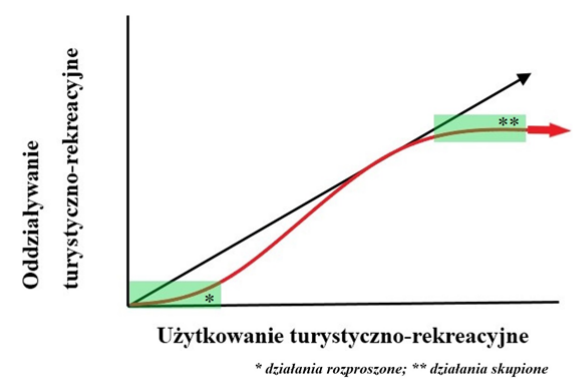

Ryc. 2. Relacja pomiędzy oddziaływaniem a użytkowaniem terenów rekreacyjnych (opracowanie własne na podstawie: Hammitt, Cole 1998: 15-17; Płoskonka 2018: 96)

Natężenie ruchu turystyczno-rekreacyjnego nie jest równomierne w czasie i przestrzeni, czego konsekwencją jest to, że obszary przyrodnicze są w różnym stopniu narażone na powstawanie szkód w szacie roślinnej i w glebie. W początkowej fazie odziaływania, środowisko przyrodnicze charakteryzuje się naturalną odpornością na presję ruchu turystyczno-rekreacyjnego (w przypadku lasu nazywaną naturalną chłonnością lasu), dlatego odziaływanie powinno mieć charakter rozproszony. Natomiast po pewnym czasie ten wpływ zaczyna rosnąć dochodząc do momentu w którym stopień zmian jest już na tyle duży, że dalsze użytkowanie nie pogarsza w znaczący sposób stanu środowiska przyrodniczego. W takiej sytuacji zaleca się skupiania odziaływań na terenach funkcjonalnych (polany rekreacyjne, szlaki turystyczne, pola biwakowe). 
W celu ograniczenia negatywnych skutków antropopresji opracowano siedem uniwersalnych zasad, których celem jest minimalizacja wpływu turysty na środowisko przyrodnicze, w którym przebywa. Zalecenia stanowią jednocześnie rdzeń koncepcji Leave No Trace (Marion, 2014: 7-80, Płoskonka 2018: 98-99).

1. Zaplanuj i przygotuj się zanim wyruszysz.

Myśl z wyprzedzeniem i przygotuj się - poświęć czas na poznanie miejsca, do którego wyruszasz, lokalnych przepisów i miejscowych zwyczajów. Zaplanuj trasę, sposób żywienia, dobierz odzież oraz ekwipunek. Sprawdź pogodę i bądź przygotowany na jej nagłe zmiany. Staraj się podróżować w małej grupie i unikaj najbardziej uczęszczanych miejsc koncentracji turystycznej. Ogranicz opakowania jednokrotnego użytku, by zminimalizować ilość potencjalnych śmieci.

2. Trzymaj się szlaków i biwakuj w odpowiedni sposób.

Staraj się nie schodzić z wyznaczonego szlaku, unikaj skrótów. Biwakuj w rozsądnej odległości od źródeł wody i stref przybrzeżnych, wyłącznie w miejscach do tego przeznaczonych, ewentualnie istniejących (pozostawionych). Jeśli nie musisz, nie twórz nowych miejsc biwakowych, natomiast jeśli rozbijasz obozowisko w dzikim miejscu, staraj się wykorzystać trwałe powierzchnie (trawa, liście, ściółka) lub drzewa (hamak). Ogranicz zasięg biwaku do niezbędnego minimum, zakładając niewielkie, rozproszone obozowiska. Redukuj wpływ na roślinność i unikaj miejsc, gdzie wpływ na środowisko dopiero się rozpoczął.

3. Zadbaj o odpady i śmieci.

Nie pozostawiaj po sobie śmieci, stosuj zasadę: przyniosłeś - zabierz z powrotem. Opuszczając obozowisko lub miejsce odpoczynku, sprawdź, czy nie zostały śmieci albo resztki jedzenia. Postaraj się, aby wszystkie odpady szczelne zapakować w worki - tak aby nie dostały się do nich zwierzęta i wynieś, ewentualnie wyrzuć do przygotowanych pojemników. Odchody, w tym zwierząt domowych, zakopuj w przygotowanym dołku, zachowując rozsądną odległość od źródeł wody. Ogranicz używanie papieru toaletowego, zrezygnuj z jednorazowych produktów higienicznych (chusteczki nawilżane). Zużyte środki higieniczne dla kobiet, podobnie jak inne odpady, wyrzucaj do przygotowanych pojemników, lub wynieś szczelnie zapakowane. Mycie naczyń powinno odbywać się z dala od źródeł wody, w wyznaczonym miejscu. Ogranicz stosowanie środków myjących (w tym biodegradowalnych) na rzecz naturalnych (piasek), nie płucz naczyń w wodzie, aby resztki jedzenia nie dostały się do niej, zabrudzoną wodę rozlej na dużej powierzchni. Myjąc ciało, staraj się ograniczać zużycie mydła i innych środków, unikaj prania rzeczy poza miejscami do tego przeznaczonymi (obiekty turystyczne).

4. Zastaną przyrodę pozostaw w stanie nienaruszonym.

Oglądaj, rób zdjęcia, ale nie zabieraj nic na pamiątkę. Pozostaw rośliny, kamienie, inne naturalne przedmioty w miejscu, gdzie je zastałeś. Unikaj przenoszenia gatunków roślin i zwierząt poza naturalne tereny bytowania. Zbierając rośliny jadalne (lub ich części), staraj się ich nie uszkodzić. Unikaj budowania trwałych konstrukcji w terenie i nie naruszaj gleby, kopiąc rowy, głębokie dziury, inne.

5. Minimalizuj skutki używania ognia. Ogień jest jednym z największych sprzymierzeńców człowieka, używaj go jednak rozsądnie, gdyż ma długotrwały wpływ na środowisko. Rozpalaj ognisko tylko, jeśli go potrzebujesz, tam gdzie jest to dozwolone. Wykorzystuj miejsca do tego przeznaczone lub istniejące paleniska. Do ogrzania 
używaj małych ognisk, staraj się ograniczać wykorzystanie ognia jako źródła światła. W miarę możliwości nie rozpalaj ognia bezpośrednio na glebie, używaj podkładów (foli aluminiowej przysypanej ziemią). Na opał zbieraj tylko martwe drewno, nigdy nie korzystaj z żywych drzew. Jeśli warunki są korzystne, używaj kuchenki do przygotowania posiłku. Po skończeniu nie pozostawiaj niedopałków, wypal ognisko do końca, zimny popiół rozsyp po okolicy. Nie pal śmieci i opakowań jednorazowego użytku (plastyk).

6. Respektuj życie dzikich zwierząt. Obserwuj dziką przyrodę z rozsądnej odległości, nie śledź zwierząt, ani ich nie płosz. Nie karm zwierząt, przechowuj szczelnie zamkniętą żywność i odpadki. Unikaj dzikich zwierząt w newralgicznych okresach, w tym godowym, wychowywania młodych, innych. Kontroluj swoje zwierzęta domowe, lub zostaw je w domu. Bądź mądry i pamiętaj, że dzikie zwierzęta nie posiadają cech filmowego jelonka Bambi.

7. Szanuj innych użytkowników terenu i szlaku.

Respektuj innych turystów, nie zakłócaj ich spokoju, pozwól im delektować się ciszą i przyrodą. Unikaj głośnego słuchania muzyki, wieczorem nie hałasuj. Omijaj miejsca koncentracji turystów, pamiętaj o obowiązujących normach prawnych. Bądź uprzejmy, tolerancyjny wobec innych przekonań, dbaj o kulturę języka.

Każda z powyższych zasad posiada oddzielny szczegółowy opis w literaturze oraz praktyczne wskazówki zastosowania. Zasady te mają uniwersalny charakter, mimo że ich rodowód wywodzi się z ochrony dzikich i odludnych terenów - tzw. backcountry (wilderness), z czasem zaczęto je adoptować do innych popularnych obszarów koncentracji turystyczno-rekreacyjnej - tzw. frontcountry (tereny rekreacyjne), a także różnych form aktywności - wędkarstwo, rowery górskie, myślistwo, inne. Oddzielny program prowadzony jest dla dzieci i młodzieży - Leave No Trace For Every Kid. Wykorzystuje on nowoczesne formy edukacji (naukę przez doświadczenie) oraz holistyczne podejście do kształcenia, głównym zaś celem jest nawiązanie i budowanie relacji z przyrodą.

Działania edukacyjne skoncentrowane są na rozwinięciu i zrozumieniu możliwości oddziaływania na środowisko naturalne, umiejętności przygotowania się na bezpieczne przebywanie w plenerze, sensu minimalizacji wpływu na przyrodę oraz podejmowania odpowiedzialnych i świadomych decyzji. Symbolem edukacji dla dzieci i młodzieży jest postać Wielkiej Stopy (Bigfoot), promująca zachowania sprzyjające naturze.

Upowszechnianie wiedzy uzależnione jest od docelowej grupy odbiorców oraz pożądanego zakresu wiadomości. Bierny przekaz wykorzystuje formę broszur (ryc. 3), książek, tablic informacyjnych oraz z zastosowaniem internetu. Najcenniejszy jest jednak przekaz bezpośredni odbywający się na trzech poziomach zaawansowania (Marion, Reid 2001: 85):

- warsztaty środowiskowe - pogadanki mające na celu zapoznanie z ideą i zasadami LNTOE. Najczęściej odbywają się $\mathrm{w}$ formie prezentacji na miejscu lub krótkich zajęć w terenie, prowadzone są przez trenera LNTOE;

- kurs trenerski - dwudniowe szkolenie wprowadzające (skrócona wersja kursu Master Educator) pozwalające zrozumieć praktyczne implikacje programu LNTOE, etykę środowiskową oraz nabyć podstawowe umiejętności w terenie, prowadzone przez Master Educatora LNTOE;

- kurs Master Educator (ME) - pełny pięciodniowy kurs dla osób zajmujących się szkoleniem z zakresu edukacji plenerowej (outdoor). Osoby po ukończeniu kursu nabywają kompetencje do samodzielnego prowadzenia szkoleń LNTOE. 


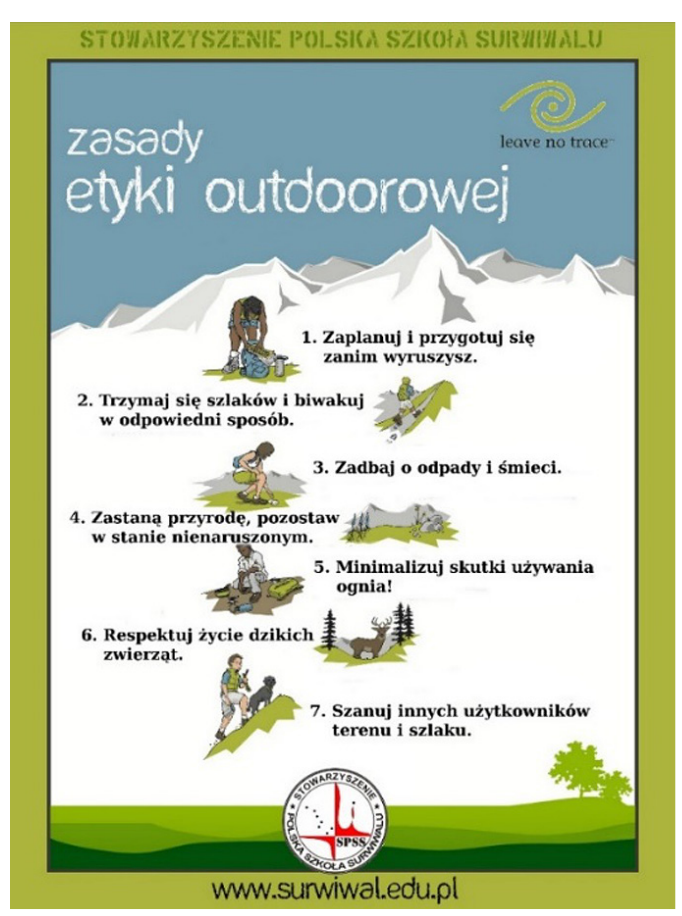

Ryc. 3. Karta referencyjna z zasadami Leave No Trace (źródło: www.surwiwal.edu.pl)

\section{Leave No Trace - współczesne wyzwania}

Niewątpliwy sukces, jaki osiągnął program LNTOE, nie uchronił go od rodzących się w ostatnich latach wątpliwości i krytyki zarazem ze strony środowisk akademickich, jak i ekologicznych, a wynikających z nowych wyzwań związanych ze zrównoważonym rozwojem. Dotychczasowe doświadczenia programu wskazują, iż:

- $\quad$ edukacja wpływa na zwiększenie świadomości społecznej i wzrost poparcia dla etycznych postaw wobec przyrody,

- edukacja przyrodnicza, pomijajacca informacje o wpływie (impact) człowieka na środowisko, nie redukuje samego wpływu,

- $\quad$ istotna jest interpretacja wpływu na środowisko przyrodnicze, a tym samym kluczowa staje się rola edukatora leśnego,

- istotnie różne są postawy deklaratywne od tych rzeczywistych - decydująca jest rola przekonań i wartości (Buckley, Littlefair 2007: 324).
Turner (2002: 478-479) zauważa jednak, że model LNTOE skupia się na ochronie dzikich terenów jako krajobrazu rekreacyjnego, pomija przy tym szerszy - a wręcz globalny - kontekst konsumpcyjnego nastawienia do zasobów naturalnych. W relacjach człowieka z otaczającą go naturą zwraca się bardziej uwagę na estetyczny wymiar przyrody, niż praktyczną wiedzę o zrównoważonym wykorzystaniu zasobów przyrodniczych. Tworzy się uproszczony obraz, iż wystarczy nie pozostawić śladu w dziczy, aby ochronić przyrodę, redukując w ten sposób wpływ etyki na codzienne zachowania środowiskowe. Ponadto, jak zauważają Simon i Alagona (2009:), w aktualnym hierarchicznym modelu LNTOE (ryc. 4) indywidualni turyści stają się pasywnymi odbiorcami etyki środowiskowej, swoistymi etycznymi konsumentami, którzy przestrzegają przepisów, biorą udział w programach edukacyjnych i użytkują przeznaczone dla nich produkty outdoorowe. Nie przyczynia się to jednak do tworzenia efektywniejszej polityki rządowej, upowszechniania wiedzy lub udoskonalania nowych produktów. Zwrócono również uwagę na coraz silniejsze powiązania ze środowiskiem biznesu, prowadzące do stworzenia swoistej marki LNTOE. Zaangażowani partnerzy sprzedają m.in. sprzęt i wyposażenie outdoorowe opatrzone logo projektu, tworząc złudne wrażenia, iż jest on bardziej przyjazny dla środowiska.

Simon i Alagona (2009: 29) zaproponowali nowy demokratyczny model, który nazwali Beyond Leave No Trace (BLNT, ryc. 5). Jego istotą jest stworzenie wspólnej przestrzeni współpracy wszystkich partycypantów (w tym turystów) w tworzeniu nowych regulacji prawnych, udoskonalaniu programów edukacyjnych i wyznaczaniu nowych kierunków rozwoju sprzętu outdoorowego. Model odrzuca pasywność turysty na rzecz współodpowiedzialności i świadomości. Model ma być propozycją dalszych zmian i kierunkiem rozwoju LNTOE w przyszłości, wychodząc poza etykę środowiskową na rzecz świadomych zachowań konsumenckich. Jest to również odpowiedź na 

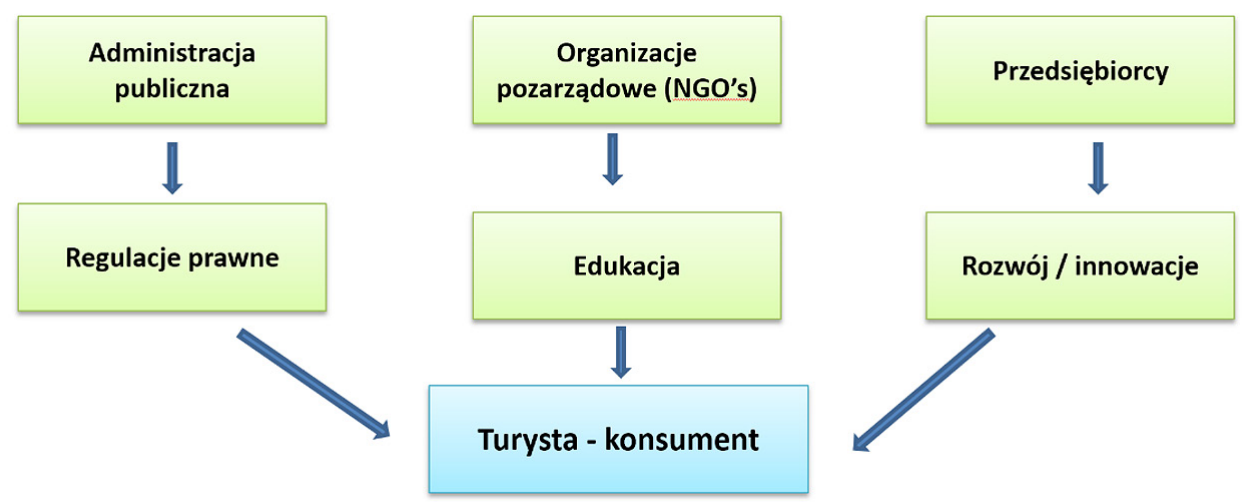

Ryc. 4. Hierarchiczny model Leave No Trace (Simon, Alagona 2009: 29)

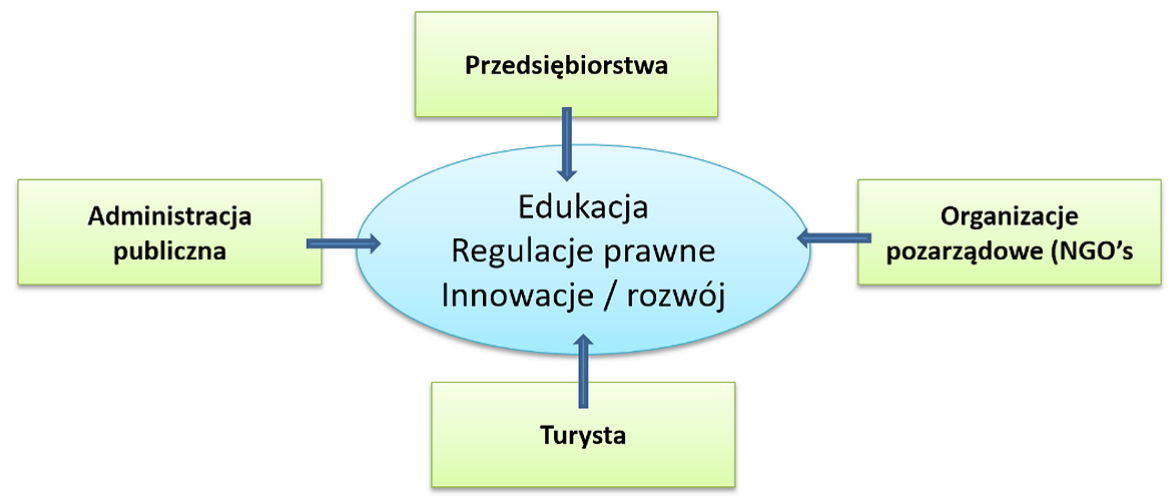

Ryc. 5. Demokratyczny model Beyond Leave No Trace (Simon, Alagona 2009: 30)

wyzwania edukacji na rzecz zrównoważonego rozwoju. Do najważniejszych założeń należą: kształcić siebie i innych o miejscach, które zamierza się odwiedzić; kupować tylko niezbędny i potrzebny sprzęt oraz odzież; dbać i konserwować, a tym samym przedłużać żywotność posiadanego sprzętu oraz odzieży; dokonywać świadomych wyborów żywności, sprzętu i odzieży; minimalizować produkcję odpadów i śmieci; starać się zmniejszać zużycie energii oraz zaangażować się w ochronę odwiedzanych miejsc.

Model LNTOE jest również krytykowany przez środowiska ekologiczne, które zarzucają mu, iż stoi w konflikcie z najważniejszymi zasadami ekologii. Moskowitz i Ottey (2006: 17) podkreślają, że właściwe postępowanie osób podróżujących w dzikie miejsca pozwala uniknąć wizualnych skutków dla krajobrazu, same w sobie jednak nie ochroni tych miejsc. Świat natury nie jest muzeum i ludzie zawsze zostawiają „ślad”, lub mają wpływ na środowisko, jak wszystkie żywe istoty. Obserwując, jak wpływamy na świat przyrody, możemy zacząć odkrywać wzajemne powiązania między nami (jako jednostka i jako część ludzkości) a otaczającym nas światem i w naturalny sposób łączyć nasze życie codzienne z zachowaniem $\mathrm{w}$ naturze.

Autorzy zaproponowali siedem zmodyfikowanych zasad LNT zgodnych z koncepcją Świadomego Oddziaływania na Środowisko 
(Conscious Impact Living; Moskowitz, Ottey 2006: 18-19):

- $\quad$ żyj w prosty sposób: dostrzeż różnicę pomiędzy chcieć a potrzebować, minimalizuj w swoim życiu zbędne przeładowanie. Podróż w dzikie miejsca pomoże ci zrozumieć tę różnicę;

- myśl globalnie i planuj z wyprzedzeniem: sprawdź możliwe konsekwencje swoich wyborów zarówno dla siebie, jak i dla otoczenia. Dokonuj świadomych wyborów, aby zmaksymalizować pozytywne i zminimalizować negatywne konsekwencje;

- bądź zapobiegawczy: trudno jest znać konsekwencje naszych działań na inne stworzenia świata. Przyjmij negatywne konsekwencje, dopóki nie masz dowodów na to, że jest inaczej;

- redukuj zużycie surowców: minimalizuj ilość odpadów poprzez ograniczenie tego, co używasz, ponowne wykorzystanie tego, co potrafisz i recykling tego, czego już nie możesz używać. Naucz się, jak konserwować i naprawiać uszkodzony sprzęt, a nie wymieniać na nowy;

- podążaj za naturą i staraj się z nią współgrać: staraj się, aby schronienie, podróże i inne działania wtapiały się w środowisko, a nie wyróżniały. Wykorzystuj naturalne warunki, a nie walcz z nimi. Dostrzeż sensoryczny wpływ, jaki masz na dziką przyrodę i innych ludzi;

- stosuj odpowiednie technologie i technologie odpowiedzialne: szukaj odpowiednich źródeł paliwa do gotowania, ogrzewania, oświetlenia i transportu. Szukaj technologii, które wspierają, a nie niszczą integralność dzikich miejsc i naturalnych systemów;

- okazuj szacunek i współczucie dla wszystkich form życia: podejdź do wszystkich części świata z szacunkiem, współczuciem, wdzięcznością i świadomością swojej części w ramach większej całości.

\section{Podsumowanie}

Realizowana od ponad dwudziestu lat w Polsce edukacja przyrodniczo-leśna, obejmuje większość zagadnień związanych z wiedzą o środowisku leśnym i prowadzeniem gospodarki leśnej. Dzięki staraniom leśników, pracowników parków narodowych i krajobrazowych informacje te docieraja do wielu grup społecznych, tematyka zaś prowadzonych zajęć edukacyjnych i warsztatów jest ciągle zmieniana i dostosowywana do konkretnych grup odbiorców (ryc. 6).

Las jest szczególnym środowiskiem dla edukacji - jego wyjątkowa złożoność, możliwość bezpośredniego kontaktu z „dziką" przyrodą wywołują określone emocje u odbiorców i sprzyjają osiągnięciu efektu w postaci pozytywnego nastawienia do przyrody, z którą - dzięki zajęciom w leśnym plenerze - mają bezpośredni kontakt. Może być również punktem wyjścia do osiągnięcia dalszych, bardziej złożonych celów służących m.in. kształtowaniu świadomości, że wszystkie elementy środowiska przyrodniczego oraz elementy będące wytworem człowieka są od siebie zależne - każdy człowiek swoim zachowaniem wpływa na środowisko i każdy jest odpowiedzialny za obecny i przyszły jego stan oraz jakość życia następnych pokoleń.

Jak zauważa Charzowski (2016: 56), doświadczenia ostatnich lat wskazują na potrzebę przygotowania i wdrożenia do praktyki nowego, zaktualizowanego aktu wykonawczego uwzględniającego stan obecny i możliwe do przewidzenia kierunki rozwoju modelu działalności edukacyjnej społeczeństwa, m.in. w Lasach Państwowych. Współczesny zwrot w stronę edukacji na rzecz zrównoważonego rozwoju ma zachęcać do zaangażowania się w proces poszukiwania rozwiązań dotyczących problemów środowiska oraz służyć podnoszeniu świadomości społeczeństwa w zakresie racjonalnego i odpowiedzialnego korzystania z lasu, minimalizowania wpływu człowieka na środowisko naturalne oraz przeciwdziałaniu konsumpcyjnemu nastawieniu do przyrody. Jednak, aby w pełni temu wyzwaniu 


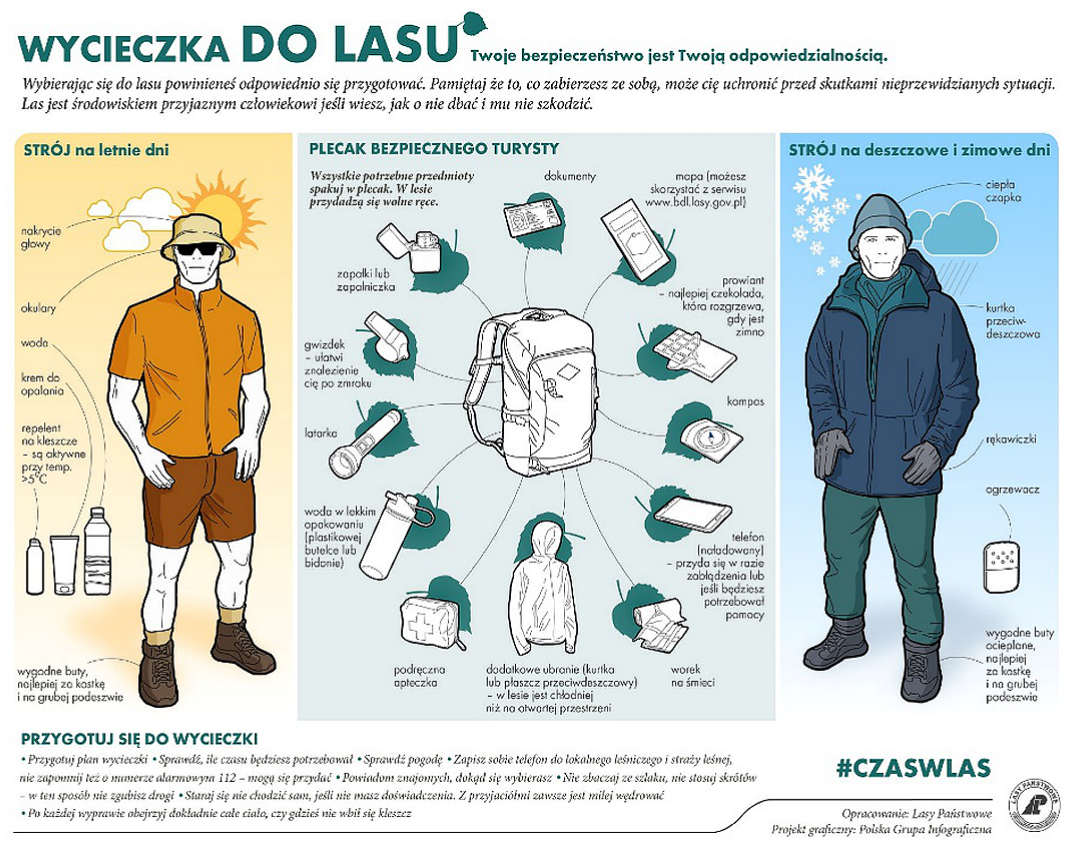

Ryc. 6. Grafiki edukacyjne przewodnika turystycznego \#CzasWLas (źródło: www.czaswlas.pl)

sprostać, edukacja przyrodniczo-leśna powinna mieć na celu przestawienie myślenia z pozycji „zdobywcy” na pozycję „partnera” środowiska naturalnego. Wymaga to również odwrócenia popularnego powiedzenia sformułowanego przez René Dubos - „myśl globalnie, działaj lokalnie” - na rzecz hasła „działaj globalnie, myśl lokalnie” (Web-o1). Przykładem takiego działania jest bez wątpienia globalny projekt LNTOE.

Jeśli edukacja przyrodniczo-leśna ma prowadzić nie tylko do ukształtowania pewnego systemu wiedzy, lecz także wartości i postaw, którymi ludzie będą się kierować w kontaktach z naturą, kluczowe jest w tym procesie zaangażowanie wszystkich partycypantów (państwo - Lasy Państwowe, NGOsy - korzystający z lasów/odwiedzający) i stworzenie wspólnej przestrzeni współpracy i wymiany doświadczeń. Adoptując rozwiązania LNTOE, czy też tworząc własne programy, należy pamiętać, że wyłącznie podejście edukacyjne jest w stanie zdobyć poparcie społeczeństwa, regulacyjne zaś ograniczenia jedynie antagonizują zaangażowane strony.

\section{Bibliografia}

Bradley J.A., 1979, A human approach to reducing wildland impacts, w: Ittner R., Potter Agee D.J.K., Anschell S. (red.), Proceedings. Recreational Impact on Wildlands, US Forest Service Pacific Northwest Region, Portlland, 222-226.

Bridle K., Kirkpatrick J., 2005, An analysis of the breakdown of paper products (toilet paper, tissues and tampons) in natural environments, Tasmania, Australia, Journal of Environmental Management, vol. 74, 1, 21-30.

Buckley R., Littlefair C., 2007, Minimal-impact education can reduce actual impacts of park visitors, Journal of Sustainable Tourism, vol. 15, 3, 324-325. Cole D.N, 2018, Leave No Trace: How it Came to Be (https://leopold.wilderness.net/history-of-wilderness-science/History\%2oPapers/Leave-No-Trace-Revisionpdf.pdf) Aldo Leopold Wilderness Research Institute, Missoula, Montana,1-14.

Cole D., Monz Ch., 2003, Impacts of camping on vegetation: Response and recovery following acute and chronic disturbance, Environmental Management, vol. 32, 6, 693-705.

Cilimburg A., Monz Ch., Kehoe S., 200o, Wildland recreation and human waste: A review of problems, 
practices, and concerns, Environmental Management, vol. 25, 6, 587-598.

Gerba C.P.,1987, Transport and fate of viruses in soils; field studies, in: Human viruses in sediments, sludges, and soils, Rao V.C. (ed.), CRC Press, Boca Raton, 142-154.

Chrzanowski T., 2016, Model edukacji leśnej spoteczeństwa w Lasach Państwowych, Studia i Materiały CEPL w Rogowie, r. 18, z. 47/2, 47-57.

Hammitt W.E., Cole D.N., 1998, Wildland Recreation: Ecology and Management, New York, John Wiley \& Sons.

Knight R., Cole D., 1991, Effects of recreational activity on wildlife in wildlands, in: Transactions of the 56th North American Wildlife \& Natural Resources Conference, 238-246.

Kowalczyk A., 2008, Wspótczesna turystyka kulturowa - między tradycją a nowoczesnościa, w: Kowalczyk A. (red.), Turystyka kulturowa. Spojrzenie geograficzne, Wydawnictwa UW, Warszawa, 9-57.

Kulik R., Kukowska I., 2010, Zrozumieć siebie na nowo. 10 zasad jak uczyć o przyrodzie, by poszerzyć swoje mate Ja, Zeszyty Ekologiczne, vol. 2, Pracownia na rzecz Wszystkich Istot, Bystra, 6-10. Lawhon B., Newman P., Taff D., Vaske J., Vagias W, Lawson S., Monz Ch., 2013, Factors Influencing Behavioral Intentions for Leave No Trace Behavior in National Parks, Journal of Interpretation Research, vol. 18, 1, 23-38.

Mandziuk A., 2016, Wartość lasu w edukacji przyrodniczo-leśnej, Studia i Materiały CEPL w Rogowie, r. $18, \mathrm{z} .47 / 2 /, 202-208$.

Marion J.L., 2014, Leave No Trace in the Outdoors, Stackpole Books.

Manning R.E., Valliere W.A., 2001, Coping in outdoor recreation: Causes and consequences of crowding and conflict among community residents, Journal of Leisure Research. vol. 33, 4, 410-426.

Marion J.L., Reid S.E., 2001, Development of the US Leave No Trace program: An Historical Perspective, in: Enjoyment and Understanding of the National
Heritage, Scottish Natural Heritage \& the Stationery Office, Edinburgh, 81-92.

Moskowitz D., Ottey D., 2006, Leaving 'Leave No Trace' Behind: Towards a Holistic Land Use Ethic, Green Teacher, 78, 16-19.

Płoskonka P., 2018, Edukacja na rzecz odpowiedzialnej turystyki na terenach przyrodniczo cennych - idea Leave no Trace, Studia i Materiały CEPL w Rogowie, r. 20, z. 55 /1, 93-102.

Reid S., Marion J., 2005, A comparison of campfire impacts and policies in seven protected areas, Environmental Management, vol. 36, 1, 48-58.

Simon G., Alagona P., 2009, Beyond Leave No Trace, Ethics, Place \& Environment. Publisher Routledge, vol. 12, 1, 17-34.

Swain R., 1996, Leave No Trace - Outdoor Skills and Ethics Program, International Journal of wilderness, vol. 2, 3, 24-26.

Turner J.M., 2002, From Woodcraft to 'Leave No Trace': Wilderness, Consumerism, and Environmentalism in Twentieth-Century America, in: Environmental History, Oxford University Press, vol. 7, 3, 462-484.

Ward C., Roggenbuck J., 2003, Understanding park visitor's responses to interventions to reduce petrified wood theft, Journal of Interpretation Research, vol. 8, 1, 67-82.

Węsławski J.K., 2015, Tylko przez szybkę, Dzikie Życie, 7-8, 253-254.

(Web-o1) https://en.wikipedia.org/wiki/Think_globally,_act_locally (dostęp: 25.07.2018).

(Web-02) https://en.wikipedia.org/wiki/Backpacking (dostęp: 25.07.2018).

(Web-03) www.lnt.org (dostęp: 25.07.2018).

(Web-04) http://etsetoninstitute.org (dostęp: 25.07.2018).

(Web-05) www.surwiwal.edu.pl (dostęp: 25.07.2018). 


\section{Concept of education for environmental ethics on forest areas: The Leave No Trace idea}

\section{Abstract}

The article is characterised by a popular concept in the world of education for environmental ethics (ethics outdorowa): Leave No Trace. Initially, the programme was directed mainly toward environments associated with the mountain-guides, climbers and hikers in response to devastation and littering. Now, it has been extended to other natural areas, including the environment as a whole. As a model of environmental ethics (outdoor), Leave No Trace promotes responsible attitude (raising awareness). The core of the concept is based on the seven universal principles, which, in combination with transferred knowledge and acquired skills, are designed to minimise human impact on the natural environment.

\section{Keywords}

environmental education, forest areas, Leave No Trace 